Article

\title{
Explaining Urban Sustainability to Teachers in Training through a Geographical Analysis of Tourism Gentrification in Europe
}

\author{
Carlos Martínez-Hernández ${ }^{1, *(1)}$ and Claudia Yubero ${ }^{2}$ (B) \\ 1 Department of Didactic of Experimental, Social and Mathematics Sciences, Universidad Complutense de \\ Madrid, 28040 Madrid, Spain \\ 2 Department of Geography, Universidad Complutense de Madrid, 28040 Madrid, Spain; \\ claudiayubero@ucm.es \\ * Correspondence: cmartinezhernandez@ucm.es
}

Received: 20 November 2019; Accepted: 12 December 2019; Published: 20 December 2019

check for updates

\begin{abstract}
Urban centres in Europe have been recently affected by touristification processes which endanger their sustainable development. In this context, education in urban sustainability is gaining great importance at all stages of education. It has been noticed that this issue is not appropriately presented in primary education studies where "tourism" is one of the topics to be addressed. This paper provides the design of a teaching activity for teachers in training in order to understand the process of tourism gentrification in European cities. The aim of this activity is to enable the transfer of knowledge to primary education concerning contemporary urban processes involving tourism within a framework of respect and sustainability. This activity is based on an urban geographical analysis in public squares located in touristified districts of several European cities. This is achieved by way of a visual, interactive and cartographic analysis and evaluation. This paper presents the results of the didactic experience in Madrid. The results are positive, since students develop geographic abilities, attitudes of respect, critical thinking, and contrasted knowledge about tourism gentrification. We conclude with a call for a conceptual update of contemporary urban processes involving tourism in primary education curricula and advise that teachers in training should be taken to the field to explain complex spatial phenomena.
\end{abstract}

Keywords: urban sustainability; teachers in training; tourism gentrification; geography; fieldwork; fieldtrip; Europe

\section{Introduction}

\subsection{Context and Goal}

Tourism is a phenomenon with a long tradition in Europe that has important effects on the culture, environment and economy of countries [1]. One of the most recent focuses in this area has been the impacts of tourism in urban centres, especially in heritage cities, where there is a strong conflict in the use and values of space [2].

The intensification of tourist use in central urban spaces is known as "touristification" - a term initially used to explain the process of the formal and functional change of the post-industrial city, forming the so-called "historic-tourist city" [3]. The historic tourist city is currently undergoing a process of touristification embedded in the broader context of globalisation. Touristification symptoms are the proliferation of tourism businesses, such as hotels and hostels, but also the uncontrolled growth in the number of apartments being offered by platforms such as AirBnB, the growth of leisure activities, nightlife in particular, the disappearance of traditional and local businesses, which give way to large 
global brands, and even the displacement of the resident population [4]. As the growth of urban tourism persists, processes of urban gentrification have been observed. Gentrification caused by tourism is affecting a growing number of cities around the world and is a relevant study object in the 21st century [5].

It is a challenge for a university to transfer updated knowledge in order to offer critical interpretative frameworks of the social reality which are kept separate from the mythologized visions of the tourist phenomenon, such as those collected by Jafari [6] in the "apologetic platform" (p. 41). It is an even greater challenge, and it will also be for future teachers, to preserve the values of coexistence, respect, empathy and sustainability [7]. In this sense, it is intended to follow here the vision of the Tourism Education Futures Initiative (TEFI), a network of researchers who follow sustainable tourism pedagogy (STP). The STP advocates the promotion of sustainability at all levels of education in continuous co-creation among all citizens [8,9]. Promoting knowledge of the complex realities of tourism in the city to future teachers contributes to the reduction of the distance between the knowledge generated in the university and tourism education at all levels [10].

In higher education studies, subjects in the field of social sciences are more linked to teaching that to epistemological development [11]. Teachers do not have a minimally deep training in the tourism field. In this context, contents about tourism are expected to pass largely unnoticed in the primary stage of education, which conflicts with the growing importance this industry has recently acquired in the political, social, environmental and economic future of Europe and the world [12].

Thus, it is convenient to introduce the topic of urban transformations linked to the intensification of the tourist use of space in primary education to offer students the basic tools for understanding the phenomenon. For this, the aim of this research is the design—and the subsequent implementation-of a group activity based on fieldwork and a constructivist approach to learning with teachers in training. The purpose is that future teachers will understand, by using urban geography tools and encouraging meaningful and active conceptual, procedural and attitudinal learning, how this discipline provides a broader framework including the dynamics of the intensification of tourist use of urban spaces. This can improve the quality of tourism education and the didactic quality of social sciences.

\subsection{State of the Research Field}

\subsubsection{Tourism Gentrification}

Since the beginning of the 21st century, a stream of research has emerged that critically reviews urban geography studies and provides new keys to the process of contemporary tourism, contextualizing it in the neoliberal turn of the city's production. This movement takes roots in urban gentrification studies [13] and proposes the concept of tourist gentrification [14]. The concept of gentrification designates a process that combines the rehabilitation of historic and popular centres with population substitution by residents with greater purchasing power [13]. It is accompanied by an increase in the cost of access to housing, the dismantling of traditional businesses and the different use of public space. The increasing tourist functionality of urban spaces is related to the last stage and/or modality of gentrification [15].

Tourist gentrification was first defined by Gotham [16] as the transformation of a middle-class area into a relatively affluent and exclusive enclave marked by a proliferation of corporate entertainment and tourism venues. One of the most studied tourist gentrification vectors is the introduction of tourist apartments in residential areas with the help of P2P platforms such as AirBnB [14,17]. Also, tourism and residential gentrification induce commercial gentrification [5]. As a consequence, changes at a symbolic and material level appear, such as an increase in prices, the expulsion of former residents and businesses and replacement by a new resident class and a new functional profile of the space. This change of urban landscape, in turn, attracts new visitors.

Spaces are transformed according to the needs of affluent consumers, whether tourists or residents in the immediate environment $[14,16]$. Many authors have observed a "commercial update" in the 
urban centres, which work to attract tourists. Stores that supply goods and services of daily necessity are replaced by those that address "affluent" needs [14,18-20]. Tourism plays an important role in the location of large chains and franchises, producing a banalized landscape of "franchise cities" [21].

Spaces are adapted to and consumed by a new cosmopolitan middle class that reproduces similar urban environments wherever it goes [22]. In practice, the behaviour of new residents and tourists is increasingly similar because they both adopt global models $[21,23]$. Thus, the city not only becomes an "entertainment machine" for residents, but it is also consumed by the (post) tourist who takes on the role of a "vacation resident" [3,24-26]. This global trend towards tourism consumption calls into question the complex, rich, diverse and locally sustainable meanings of each society [27].

Several European cities are the focus of recent research in tourism gentrification. London has been one of the first European cities to be studied [28,29]. In Berlin holiday flats render complex processes of urban change visible [30]. In Amsterdam, the transformation of the Red-Light district has been analysed after the implementation of a renovation plan aiming at changing the tourism image of the area [31]. Other cities within major tourist countries have also been studied such as Rome [32] and Paris [5,13,33]. In Lisbon, the rehabilitation of buildings and public spaces, and the growth in the number of holiday accommodation rentals are deeply affecting central spaces such as Alfama, Bairro Alto, Baixa, and Chiado [34-36]. In Spain, Barcelona is one of the most studied cities, for example regarding the penetration of tourism in the heart of the Raval historic district [37]. Madrid has also been studied, in areas of Centre District such as Malasaña, Chueca and Lavapiés [38-40]. Their common trajectory tells a story of a first degradation and appropriation of spaces by alternative and marginalised social groups that become "fashionable" areas over time. This is the case, for example, with the "Madrid movement" in Malasaña, or the homosexual community in Chueca.

These processes have led to new forms of conflict that have appeared in the urban centres of many cities as the economic crisis of 2008 coincided with a sharp rise of liberalisation of the tourism sector [41]. Tourism has been a leading activity in the entrepreneurial urbanism. Only a sustainable urban management approach based on spatial justice values can bring the coexistence of the different uses in the city. The current moment is crucial for the awareness of future teachers in the new challenges that take place in urban spaces.

\subsubsection{Geographical Fieldworks and Fieldtrips}

A didactic fieldtrip is an activity to be performed in groups outside the classroom, in a geographical space that is a source of knowledge and which students access through an experience of motivation and personal development. Álvarez Piñeros et al. [42] characterise didactic fieldtrips as the opportunity to explore, discover and rediscover a near or distant reality for students. This being a process where observation, description and explanation in situ play an essential role. Aguilera [43] finds three coincidences in all definitions: it is an activity that takes place outside the classroom, it has an educational purpose and it generates experience in students. According to Crespo Castellanos et al. [44]: “These types of activities provide students with a holistic understanding of the environment in which they operate, provide teachers with an alternative instrument to work on aspects related to space and favour the development of multicausal understanding of processes, factors and spatial elements" (Authors' own translation from p. 126).

The Council for Learning Outside the Classroom [45] emphasises that any young person should experience the world beyond the classroom, as an essential part of learning and personal development. In addition, the didactic outputs have a very positive influence on emotional, conceptual and procedural aspects, resulting in the development of observation, inquiry and discussion, all of which are elements involved in student motivation $[46,47]$.

Didactic fieldtrips or itineraries are not, in themselves, an innovative resource. Already in 1970, Sorrentino and Bell [48] noted the purposes for which this didactic instrument could be used: to foster an experience, to stimulate interest and motivation, to attribute relevance to learning, to develop observation and perception skills and to promote personal development and social skills. Throughout 
the 20th century, other authors such as John Dewey, Célestin Freinet, or Maria Montessori, to name a few, understood the need to leave the classroom [43]. This idea takes roots already in the late 19th century in the pedagogical conception of geographical hiking developed in Spain by the Institución Libre de Enseñanza (The Free Institution of Education), through the Normal Schools and the Royal Geographic Society [44].

However, despite the historical trajectory of these considerations, Pedrinaci [49] points out that as the current number of teaching fieldtrip opportunities is relatively low, it produces the sensation of novelty in the students and even teachers perceive erroneously that fieldtrips are innovative pedagogical elements. Rebelo et al. [50] attribute the small number of fieldtrips to the high number of students per classroom, dedication, extra time, economic, and administrative aspects, the scarcity of teaching materials, and the well-known civil responsibility involved in this type of action [51].

In the field of teacher training, Costillo et al. [52] point out that educational outputs not only benefit the emotional level, but also cognitive and transversal skills, increasing the quality of education. Therefore, if future teachers carry them out within their training, they will be able to see their learning of the natural, social, and cultural environment increased, and due to a cascading effect, future students will also increase their knowledge [53].

These considerations gain importance when the lessons learned are epistemologically complex, since an empirical approach to them, through an active methodology, makes them more attractive and affordable [54]. It is probably what happens with tourism education, especially in current controversial and polyhedral phenomena such as the touristification of urban spaces and tourism gentrification. Solbes [55] claims that the use of didactic fieldtrips improves the students' esteem for science education, which is a priori unattractive and disconnected from current life and society. This may be due, according to Cañas and Martín-Díaz [56], to the density of teaching programs, their own language, the need for prior knowledge, the lack of empathy between the teacher and the student. Fieldtrips can improve the lack of disciplinary and emotional cohesion [57]. Under all these considerations, it seems possible to think that a fieldtrip supported by a didactically guided analysis of urban geography can help training teachers learn and apprehend new dimensions of urban tourism in European capitals.

\section{Materials and Methods: Activity Design}

\subsection{Aim and Presentation}

The teaching activity consists of an analysis of Urban Geography on the intensification of the tourist use in urban centres and the consequent conflict between residential, touristic and leisure use, sometimes developing gentrification processes contrary to urban sustainability. Specifically, this activity is presented for areas of European capitals. Working stages are as follows (Figure 1). First, teachers have to select some public places (preferably urban squares) and design the pedestrian itinerary that connects them all. Second, a guided fieldwork takes place where students apply geographic analysis tools in order to discover structures and dynamics of tourist gentrification and answer the main research questions: Are these traditional areas where daily life can happen, or new areas recently created for tourism and consumption? Further, in relation to this, what are the effects on the city and its sustainability?

Once the public places are selected, students must reach them by a pedestrian itinerary. In each square, a group of students stays to perform the activity, and the rest continues walking towards the next square, where the next group stays, and so on until reaching the final square with the last group. Depending on the number of places to study and the length of the itinerary, a certain time frame will be established to complete the activity.

For the exercise, students are given an instruction sheet with all the information about the activity and how to carry it out, a map of the city centre, a blank sheet, and some coloured markers. They have to mark the itinerary on the city centre map and draw a new map on the blank sheet, where they have to show the square studied, the streets that start from it and the structural elements of the 
space (commerce, street furniture, terraces...). Then, on the back of the map drawn, they must explain schematically the social dynamics they observed. Specifically, they are asked to observe, describe and reflect upon the following elements:

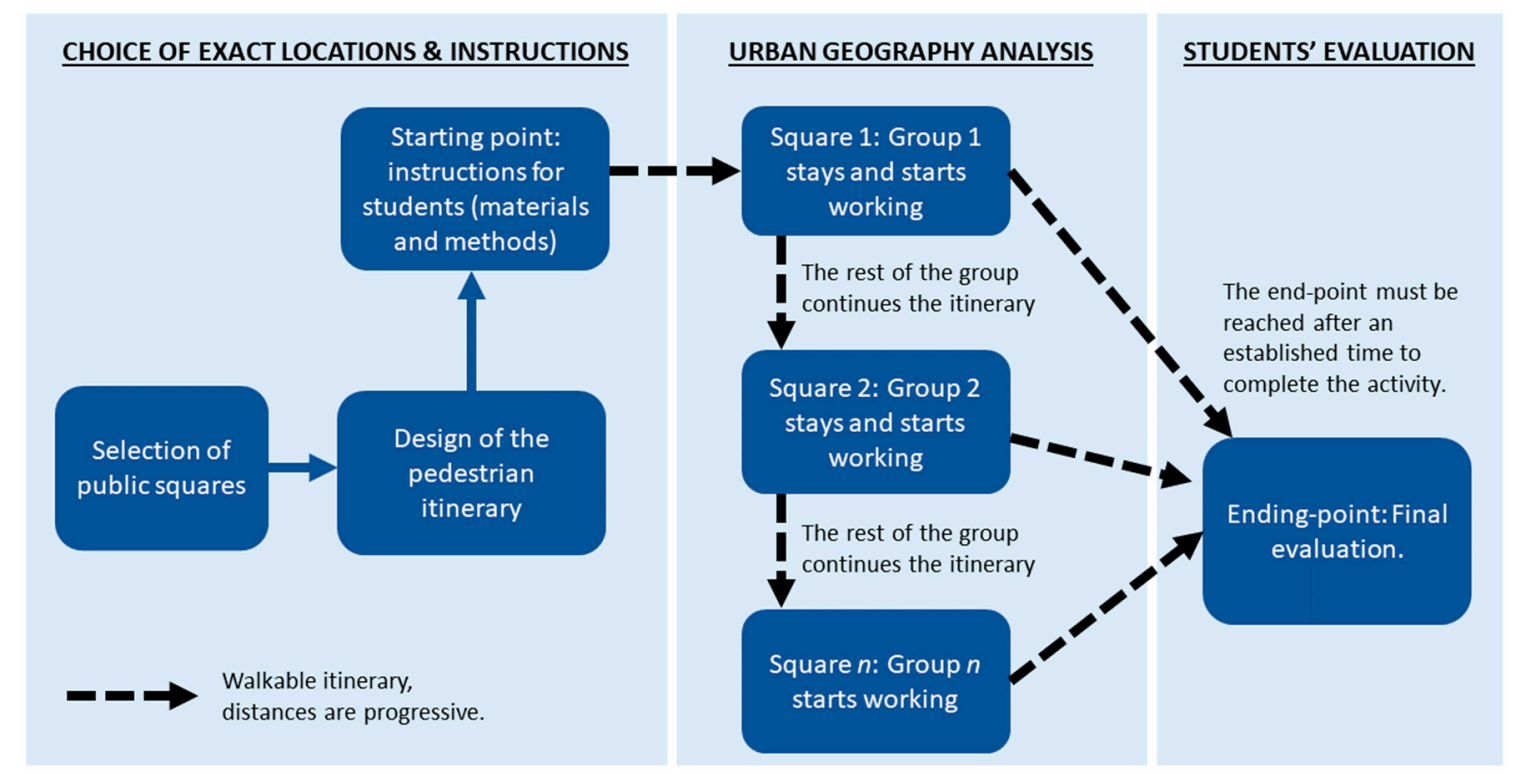

Figure 1. Model of working stages for the teaching activity.

-Local businesses and other establishments: What establishments are there? (Tourist accommodation, trade in tourist products, food, generic, fashion, tourist services, public administration, hospitality, empty premises...). What were there? (They are asked to ask pedestrians). What aesthetics do they have? Is it domestic or foreign capital?

-Urban furniture: What kind of street furniture exists? Are there banks? Are there playgrounds? Where are they? Are they practical? Is there enough space for pedestrians to walk? All types of pedestrians? Which would find it harder? Do cars drive nearby? Is there parking?

-Social dynamics: Who is in the square? Do they look like native or foreigners? Do they look like residents or tourists? Do they go alone or in groups? What are they doing? Do they socialise with each other? Are they passing by or stopping somewhere?

Finally, at a meeting point all groups share their results. At this stage of the activity, the evaluation takes place. Here, all the groups share their maps together, think about the dynamics observed, and reach general and comparable conclusions.

With the activity, physical and socioeconomic impacts will be studied within the framework of tourism gentrification processes. It is not only about perceiving improvements in the urban environment, but also other visible changes, such as in the local businesses (orientation towards the hospitality industry, fashion stores and absence of daily life stores as well as absence of equipment and services for residents), in the use of public space (saturation of public space, presence of underground parking to ensure accessibility to the centre), and in the symbolic dimension of space (creation of new values associated with consumption: authentic, ecological, bohemian, etc., and propagation of global brands and aesthetics). 


\subsection{Objectives and Competences}

Under the pedagogical, academic and methodological considerations mentioned above, the general purpose of the activity is to contribute to the training of the future teachers in current tourist phenomena and achieve a subsequent transfer of knowledge to the primary education stage, by means of an active learning methodology based on a didactic fieldtrip and a fieldwork in Urban Geography.

The European Higher Education Space has led to the homogenisation of higher studies in Europe, establishing a homologated ECTS credit system and a competency assessment system, not rigidly restricting the autonomy of the academic world but as a way to set benchmarks and convergence [58]. Within this framework, the general objective of this work allows the development of a good number of generic key competencies (ability to learn; communication skills; skills to work in groups; problem solving; autonomy; reflection skills; interpersonal skills; planning and time management; decision making; appreciation of diversity and multiculturalism; ethical commitment; critical and self-critical ability; ability to improve one's performance and learning, including the development of study and research skills; ability to analyse and summarise, evaluate, identification of problems and proposal of solutions; solid knowledge of the professional practice), as well as the development of the following specific competences of the area of Education Sciences (numbering is in accordance with the original source) [59]:

1. To be able to analyse educational concepts and theories and educational policy issues in a systematic way.

2. To be able to identify the potential links between knowledge and its application to educational policies and contexts.

3. To be conscious about one's own system of values.

5. To be capable of recognising the diversity of students and the complexities of the learning process.

6. To be aware of the different contexts in which learning can take place.

7. To be aware of the different roles of those who participate in the learning process.

9. To be able to conduct an educational research in different contexts.

11. To be able to manage projects for improvement and school development.

12. To be able to manage educational programs.

13. To be able to evaluate educational programs and materials.

14. To be able to anticipate new educational needs and demands.

15. To be able to lead or coordinate multidisciplinary educational teams.

17. To be competent in various teaching/learning strategies.

19. To know the subject matter to be taught.

20. To be able to communicate effectively with groups and individuals.

21. To be able to create a climate that facilitates learning.

23. To be able to manage time effectively.

25. To be aware of the need for continuous professional development.

26. To be able to evaluate the learning outcomes and student achievement.

27. To be competent in collaborative problem solving.

29. To be able to respond to the diverse needs of the students.

30. To be able to adapt the curriculum to a specific educational context.

At the curricular level, the specific objectives pursued with this teaching experience, as well as the procedures designed to achieve them, are specified in Table 1 . Their transfer to the primary educational stage is specified in the contents related to the social and civic sciences included in each member state's curricular legislative development. 
Table 1. Objectives and procedures of the teaching experience.

\begin{tabular}{|c|c|c|}
\hline & Objective & Procedure \\
\hline a. & $\begin{array}{l}\text { To orientate geographically and to use } \\
\text { cartographic and geolocation tools. }\end{array}$ & $\begin{array}{l}\text { Urban itinerary between different } \\
\text { significant public squares. }\end{array}$ \\
\hline b. & $\begin{array}{l}\text { To develop techniques for critical and systematic } \\
\text { observation of territorial space. }\end{array}$ & \multirow{3}{*}{$\begin{array}{l}\text { Identification of urban structures } \\
\text { and dynamics of the study area. }\end{array}$} \\
\hline c. & $\begin{array}{l}\text { To acquire social interaction skills as a source of } \\
\text { knowledge of territorial dynamics. }\end{array}$ & \\
\hline d. & $\begin{array}{l}\text { To recognise the structures and dynamics of a } \\
\text { geographical space. }\end{array}$ & \\
\hline e. & $\begin{array}{l}\text { To understand the process of tourist } \\
\text { gentrification, in its diagnosis, causes and effects. }\end{array}$ & \multirow{2}{*}{$\begin{array}{l}\text { Cartographic representation of } \\
\text { urban structures and dynamics } \\
\text { activity and the final sharing } \\
\text { activity. }\end{array}$} \\
\hline f. & $\begin{array}{l}\text { To reflect on the consequences of the } \\
\text { intensification of the tourist use of urban centres. }\end{array}$ & \\
\hline g. & $\begin{array}{l}\text { To design cartographic elements of spatial } \\
\text { representation. }\end{array}$ & $\begin{array}{l}\text { Cartographic representation of } \\
\text { urban structures and dynamics } \\
\text { activity. }\end{array}$ \\
\hline h. & $\begin{array}{l}\text { To value the importance of field work as a } \\
\text { teaching resource. }\end{array}$ & \multirow{3}{*}{ Full activity. } \\
\hline i. & $\begin{array}{l}\text { To know basic procedures of urban geographic } \\
\text { analysis. }\end{array}$ & \\
\hline j. & $\begin{array}{l}\text { To find out urban realities outside students' } \\
\text { surroundings. }\end{array}$ & \\
\hline
\end{tabular}

\subsection{Didactic Evaluation}

In order to understand the extent to which the educational objectives of this teaching experience are achieved, the resolution of a questionnaire (Table 2) is proposed, to be completed by the students a few days after the activity. In addition, direct observation and the outputs of the final sharing activity are also considered. The questions are structured in two blocks of content: the first one evaluates the analysis of urban geography and the second one shows some general conclusions about the contributions of the activity. The questions are in several formats: (i) closed questions to answer according to a Likert scale from 1 to 5; (ii) closed multiple-choice questions, sometimes single-answer and sometimes multi-answer; and (iii) open questions with a short answer.

Finally, we homogenised and normalised the answers in a spreadsheet, through a matrix of data that we described statistically. This allowed us to quantify and critically assess the degree of achievement of the objectives of the teaching experience, through a mixed quantitative-qualitative approach. 
Table 2. Students' questionnaire.

PART A:

Urban Geography Analysis

1. Mention two central areas with great socioeconomic dynamism today.

(Answer)

2. What is the main characterisation of the urban structure of these areas?

O Presence of shops, restaurants and bars

O Large open spaces O Distance from subway

3. What is the main consequence of the intense social and economic dynamics of these areas?

O Price increase

O Residents expulsion

O The previous two answers are true

4. Did you find the observation of the environment and

$\mathrm{O}$ Yes

drawing the map helpful to you to carry out this analysis of

O No

O Other:

5. Have you had to interact with pedestrians to solve the exercise? Answer Yes or No and, if so, briefly explain if it was satisfactory.

(Answer)

6. What difficulties have you encountered when performing this practical activity of geographical analysis?

$\begin{array}{ll}\text { 7. Have you learned new skills and geographic content? } & \text { (Answer) } \\ \begin{array}{l}\text { 8. Do you think it is an interesting activity to apply in the } \\ \text { educational field? }\end{array} & \text { (Answer) }\end{array}$
educational field?

PART B:

Conclusions (Contributions of the Activity) [Evaluate from 1 (Poor/Bad) to 5 (Good)]

\begin{tabular}{ll}
\hline 1. Personal experience: & (Answer) \\
\hline 2. Cultural learning: & (Answer) \\
\hline 3. Social skills: & (Answer) \\
\hline 4. Living with different people: & (Answer) \\
\hline 5. Managing schedules: & (Answer) \\
\hline 6. Urban mobility: & (Answer) \\
\hline 7. Knowledge of another urban reality: & (Answer) \\
\hline Others: & (Answer) \\
\hline
\end{tabular}

\subsection{Choice of Study Districts}

The activity must be carried out in areas of the main European capitals where touristification has been observed according to the scientific literature (see theoretical framework). Figure 2 shows the areas selected in this work, of different types, for several European capitals: Lisbon (Alfama), Madrid (Malasaña-Chueca), Rome (Testaccio), Paris (Le Marais), Berlin (Kreuzberg), and London (Shoreditch). 


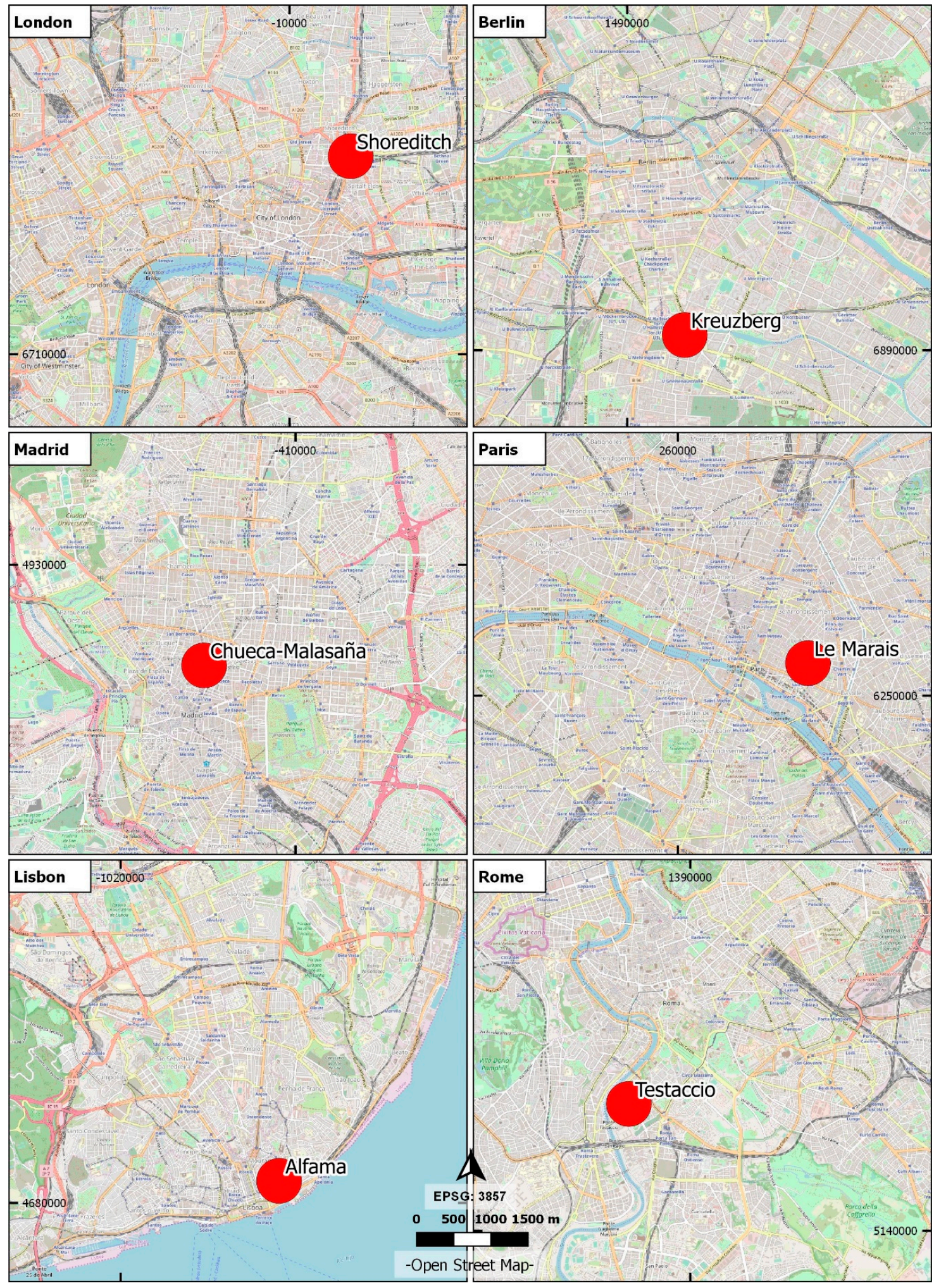

Figure 2. Localisation of districts in some European capitals as a sample for the study of tourism gentrification.

\section{Results and Discussion of an Implemented Experience}

In order to verify the effectiveness of the activity, an experience was carried out in the city of Madrid (Spain) in April 2018 with a group of students of the Degree in Primary Education of the 
Faculty of Education of the University of Murcia (assigned centre ISEN). These are 14 students in 2nd and 3rd grade, in a gender ratio of $60 \%-40 \%$ in favour of women. All are between 20 and 24 years old with only one exception (39 years old). The students of second year are enrolled in the subject "Social Sciences and their Didactics" (6 ECTS credits) and those of third year in "Didactic Methodology for the teaching of Social Sciences" (6 ECTS credits).

In the case of the city of Madrid, urban planning policies are implemented within the framework of what has been called "business planning", which indicates the importance of tourism as a major source of income [40,60]. The most noteworthy characteristics of the interventions in Madrid's urban planning policy are the actions of rehabilitation of historic buildings, the flexibility of urban planning instruments (decreasing degrees of patrimonial protection, facilities for changes in use, etc.) and the adoption of a general image of improvement of the urban environment [39].

For this experience, two significant areas in the Central District were selected, where urban sustainability is at risk: Chueca and Malasaña. The public study places were adapted to the number of students: a total of three, to be studied by groups of $4-5$ members: Pedro Zerolo, Chueca and Dos de Mayo squares, with $1300 \mathrm{~m}$ between the first and the last one (Figure 3).

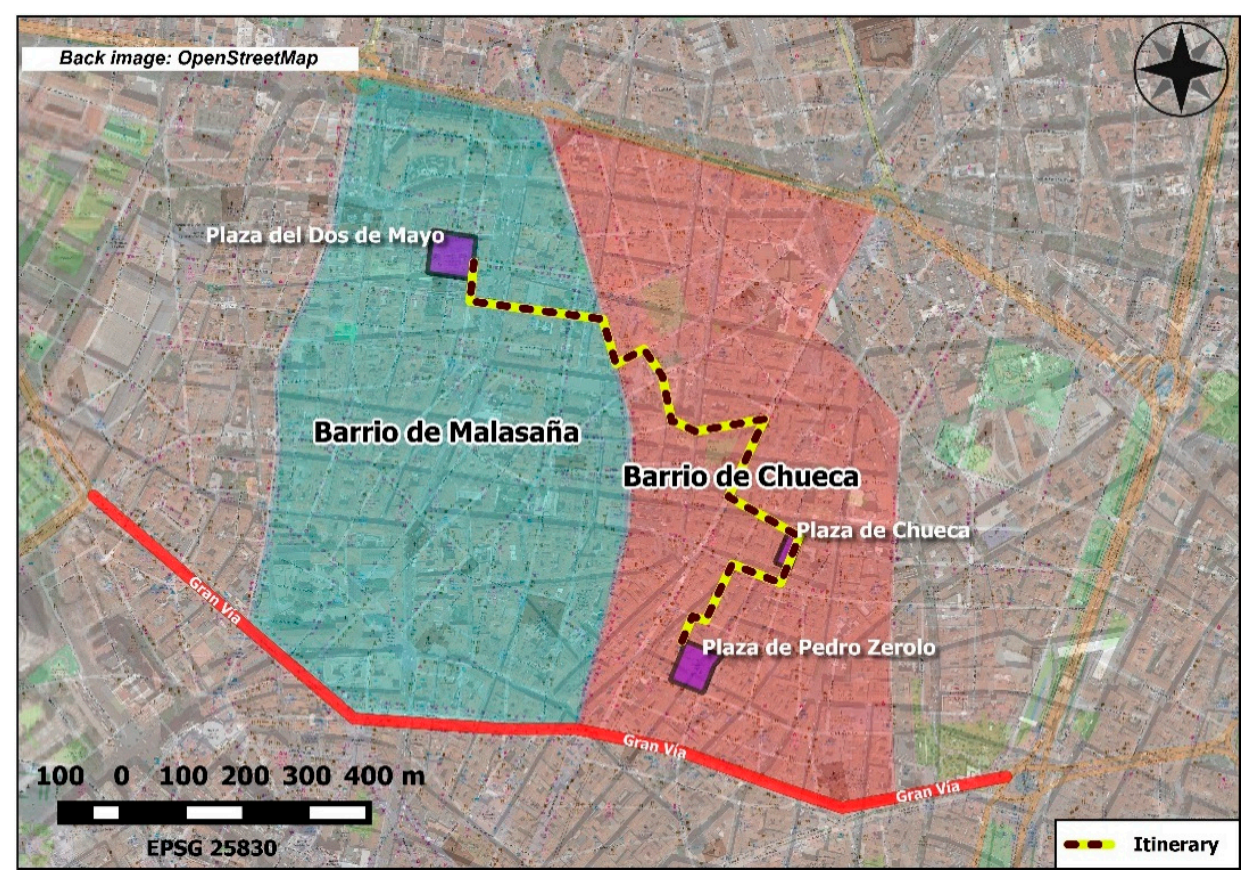

Figure 3. Itinerary followed by students to access the study places in the Madrid areas of Chueca and Malasaña in the Central District, North of Gran Vía Street.

The questionnaires completed by the students allow to know to what extent they have improved their basic knowledge in geography and tourism, as well as their assessment of the relationship between urban tourism and sustainability. Consequently, they are better trained to consider teaching these topics in their future primary classes. The final sharing activity allows to understand the causes of their results since the students explain what they have done and why.

\subsection{Degree of Achievement of the Objectives According to the Students' Perception}

Along with the use of the map (objective "a"), another geographical procedure that is sought to be developed with this activity is the observation of reality, with a critical and a slightly expert view (objective " $b$ "). By being very unfamiliar with these technical procedures of observation and representation, they engage in the activity with enthusiasm. In fact, when asked if these geographic techniques have helped them understand and perform the urban geography analysis, up to $93 \%$ of 
students responded positively (Figure 4). When experiences of itineraries or didactic fieldtrips are carried out, it is very common to develop cartographic skills [61,62].

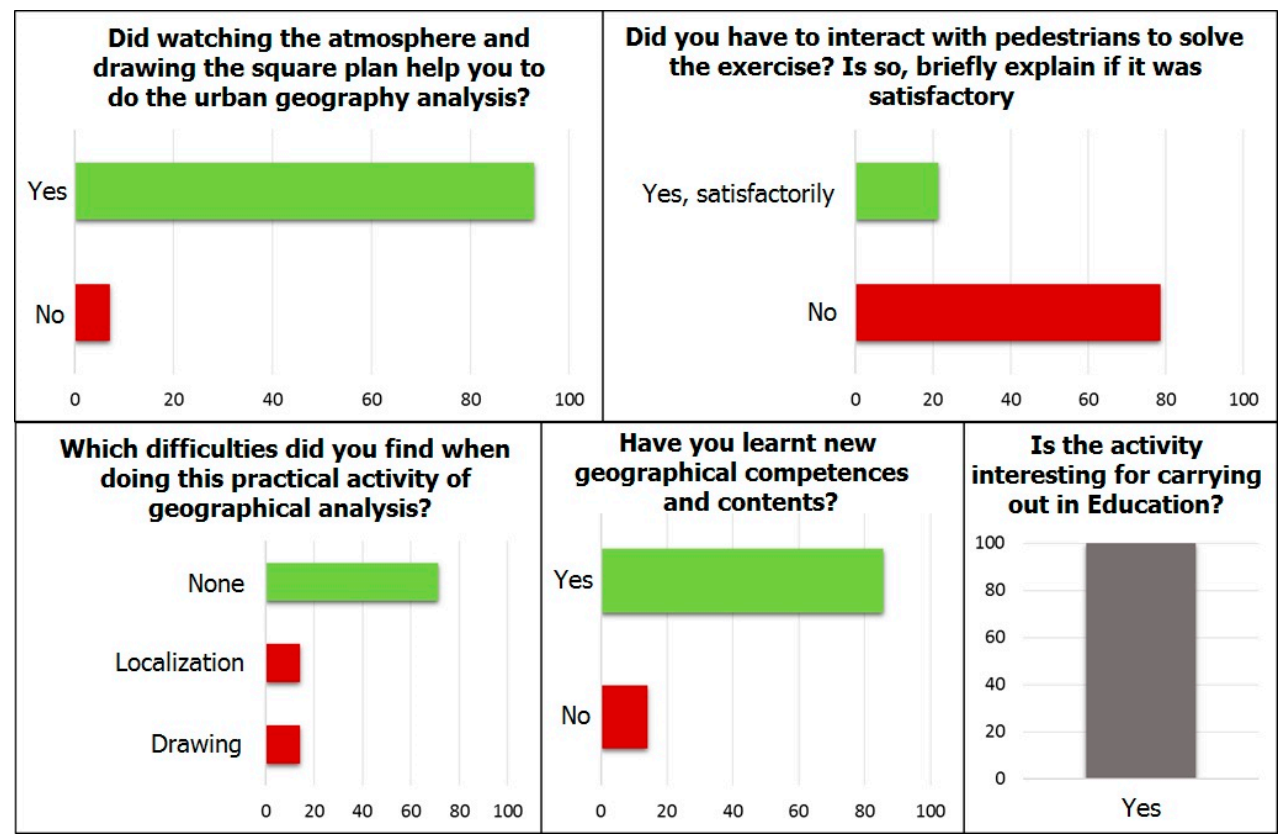

Figure 4. Normalised answers to questions about students' didactical perception.

However, social interaction is a technique that most of students have not known how to develop. Only $21 \%$ of students have interacted with pedestrians to solve the exercise (Figure 4). Most students have not dared to ask pedestrians questions, not only because of shyness and a lack of confidence, but also because they have not been aware of the importance of this analysis technique, in line with Rajala and Akkerman's warning [46]. Thus, the relevance of social interactions needs to be highlighted during the explanation of the activity in future fieldtrips.

Most of the students do not recognise any difficulty when carrying out the activity, but among the $29 \%$ that do, they refer to the geographical orientation and the skill of drawing the map (Figure 4). They have assumed the importance of working with maps and resorting to systematic observation, but they have failed to understand the need to complete the analysis by interacting with the utilitarian agents of the space they were studying.

Students are aware of what they have learnt: up to $85 \%$ acknowledge having learned new geographic skills and content (Figure 4), and the rest knew them previously. All, therefore, have mobilised research techniques that, despite being basic, they did not know or had barely used, so they can incorporate them from now on. Other experiences of fieldwork with students have also shown that this strategy achieves conscious learning in students [63,64].

Finally, students, share the importance of these new learnings, especially useful in future teachers, so that $100 \%$ of the students affirm that the activity is interesting to apply in the educational field (Figure 4). It is not only a useful experience from the scientific point of view but also didactic. This educational transfer is frequent in teaching methods outside the classroom $[65,66]$.

\subsection{Degree of Achievement of the Objectives Based on Evaluation Questions}

As for the quality of their urban analyses (objectives " $\mathrm{d}$ " and " $\mathrm{e}$ "), in relation to the transformations of the use of space induced by tourism in urban centres, it is certainly good. Despite a single case, they are able to name a central area of Madrid with a great socioeconomic dynamism, and more than $50 \%$ are able to name a second area (Figure 5). 


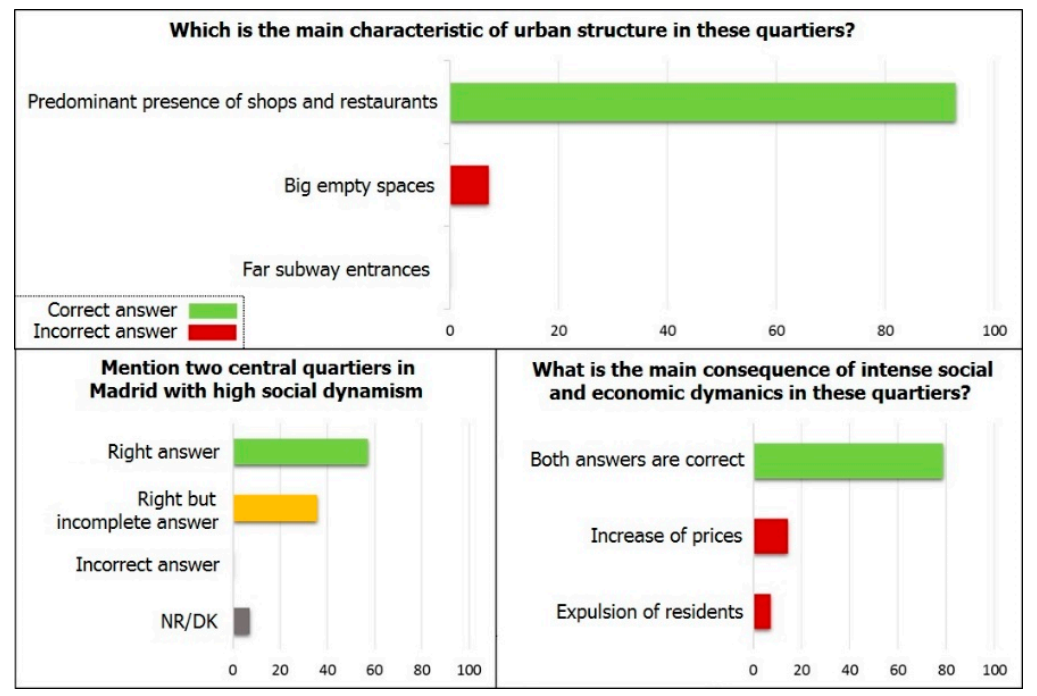

Figure 5. Normalised answers to questions about students' new knowledge.

Again, all students except one can identify the main characterisation of the urban structure of these areas: the predominant presence of shops, restaurants and bars (Figure 5). This high rate shows that they have found the key elements to identify the urban transformation of the spaces they are analysing.

This idea is confirmed among almost $80 \%$ of the students, who know how to discern the negative effects of the intense social and economic dynamics of these areas (objective " $\mathrm{f}$ "): price increase and expulsion of residents (Figure 5). These being the main effects of tourism gentrification demonstrates the successful learning of this process.

\subsection{Degree of Achievement of the Objectives from the Students' Production}

In order to observe and represent the physical and social impacts of the intensification of the tourist use of space, students are induced to reproduce on maps the observable structures and dynamics at the scale of the three study areas (objectives " $\mathrm{g}$ ", " $\mathrm{h}$ ", and "i"). To do this, they were previously offered a short definition based on several examples. Structures refer to the existing material elements and their relative position, such as buildings, streets and urban furniture. Dynamics refer to the interactions occurring in the space such as mobility (pedestrian and vehicular), material production of space (real estate constructions), but also others such as the demographic dynamics (what people live in the area, how old they are, what are their origins), as well as the social ones (how people relate to each other in space).

From the maps drawn by the students (Figure 6), the elements mentioned above can be observed. Basic cartographic techniques were performed as indicated, such as symbolisation, shaping, colouring, etc., although the orientation of the map is missing in all groups. Active cartography is a good method for understanding spatial phenomena [67]. The example of Plaza de Dos de Mayo map (probably the one with the highest visual quality), shows the urban structure and its elements recognised by its authors: the statue in the centre of the square, the banks, the playground areas, the street sales area and the corner school. It is striking that the school is recognised as the only representative building. In the subsequent questions they implied that the rest of the buildings with portals towards the square were not relevant for being almost all the same: bars with terraces. However, despite not having represented them they later knew how to give them the importance they deserve when explaining the socioeconomic dynamics in the area. In contrast, the Plaza de Chueca map is the most complete of all those presented because of the details shown regarding every business. The great majority of the students knew how to see and understand the dynamics of the urban phenomenon effect of the intensification of the tourist use of public space in large cities (objective " $j$ "). They were able to 
recognise how the residential function and the associated conventional establishments had been clearly relegated to the background, when not disappeared.

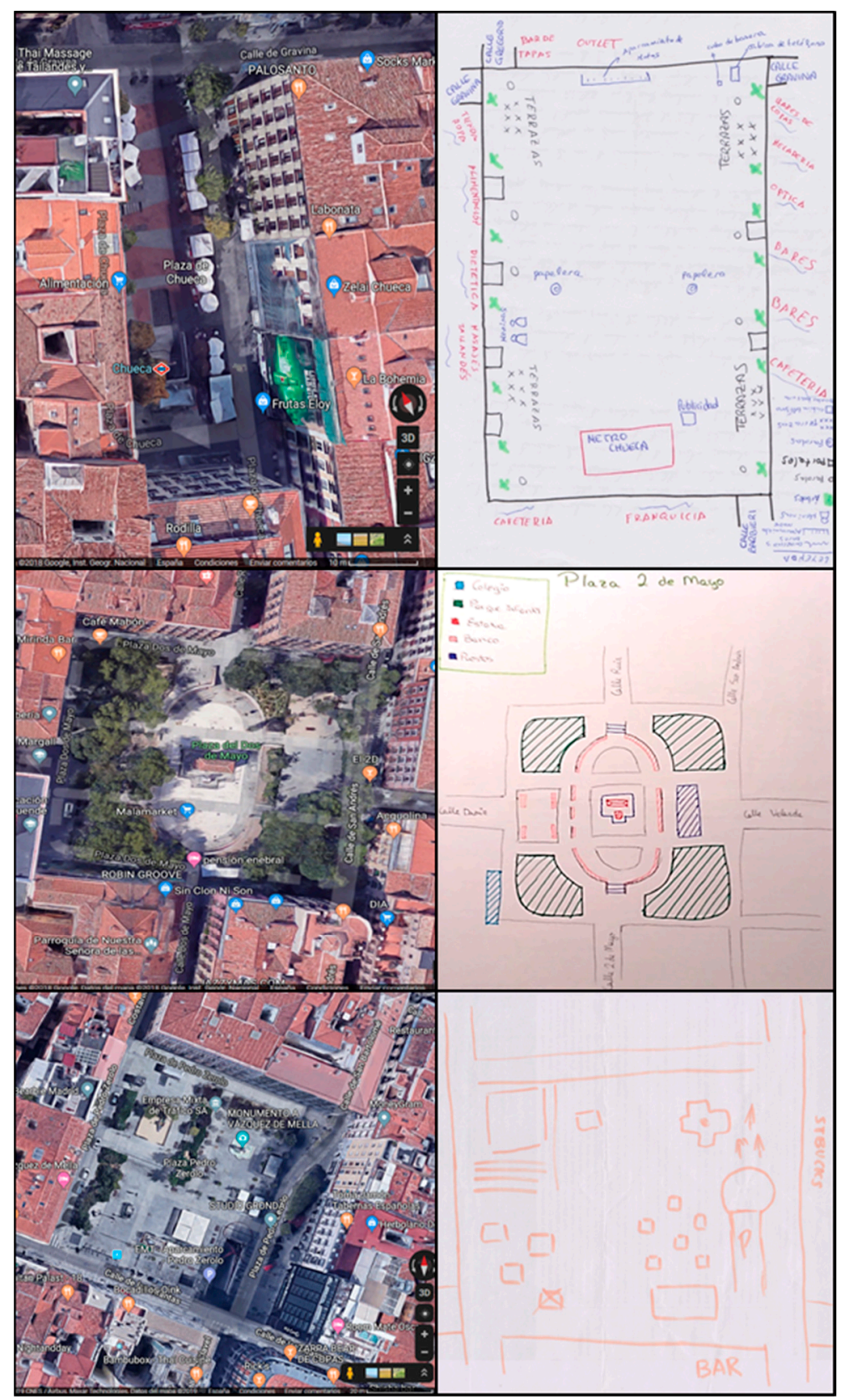

Figure 6. Maps of the study area (from top to down: Plazas de Chueca, Dos de Mayo and Pedro Zerolo; left: aerial images from Google Maps; right: students' plans).

During the discussion, the importance of the geographic tools was observed. Learning outside the classroom is not only a matter of conceptual learning but also procedural [68]. Also, an attitudinal learning was carried out both when interacting with each other outside the classroom and when reflecting on a complex phenomenon such as the effects of the intensification of the tourist use of urban space. In short, adequate promotion of different key competencies was achieved, as recommended by the European Union [69]. Of those established by the LOMCE, the current educational law in Spain [70], developed in RD 126/2014 [71] (p. 19352), the most clearly addressed are: (1st) linguistic communication, (3rd) digital competence, (4th) learn to learn, (5th) social and civic competences, 
(6th) sense of initiative and entrepreneurial spirit and (7th) cultural awareness and expressions. The achievement of these competencies is important because of the great help that these learnings will entail in the future teachers when it comes to exercising their profession, focused, in the development of the students' key competences, according to the current pedagogical paradigm [72]. The answers to the questionnaire and the map that the students themselves have drawn from their study place attest that the activity has been developed properly.

\subsection{The Geographical Fieldwork as an Integral Experience}

The Urban Geography fieldwork provided broad competence coverage and comprehensive learning based on content, procedures and attitudes, together with the joy that activities outside the classroom usually bring. Upon completion, students were asked about a series of inputs that are expected to be achieved in fieldworks. On a Likert scale from one to five, where five is the maximum value, students assessed the inputs received in this activity with an outstanding average: $4.5 \pm 0.7$ points (Figure 7). Thus, we can affirm that the use of fieldwork has not only been didactic but also fruitful for personal development, along what other authors have acknowledged $[44,52,73]$.

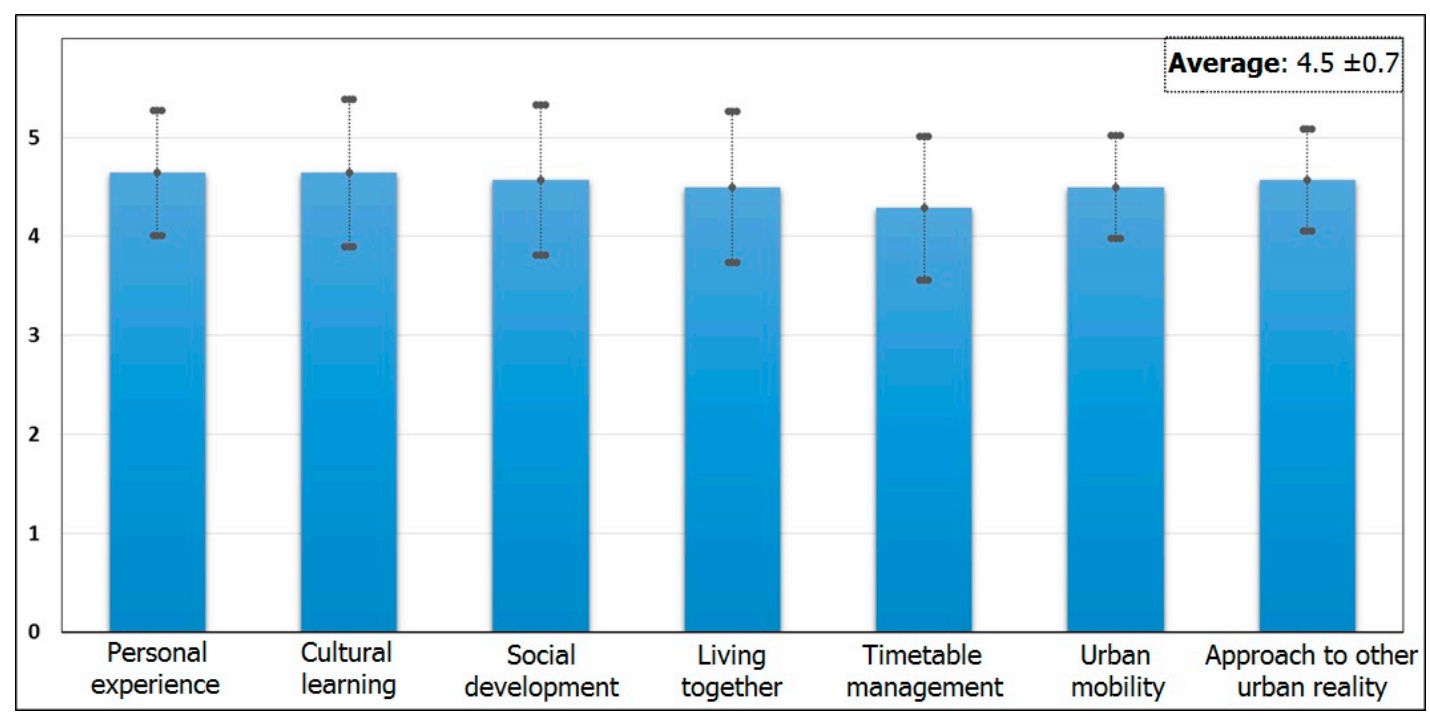

Figure 7. Students' valuation of items about fieldwork and fieldtrips.

Fieldwork supported by itineraries has proven to be widely effective covering various educational approaches from a pedagogical point of view. Guerrero [74] defends it as a "learning that starts from direct contact with reality, expanding and deepening the knowledge, skills and values that can be acquired by observing, discovering and interpreting the interaction system of any social phenomenon" (p. 227). It is about covering curricular contents that, as Rodríguez Cortés et al. [64] expose, "the classroom does not allow ... ; they are intended to approach natural environments so that students and teachers share in spaces that are meaningful and bring new experiences with them" (p. 124). As it can be seen, all these considerations coincide with the discussion of our results.

Fieldtrips and fieldworks as a teaching resource have a long tradition in geographical and environmental disciplines, especially in non-university education levels $[61,67,75,76]$. However, university experiences are also appearing, with different approaches depending on the disciplines. In degrees related to Tourism, for example, they have a professional approach and they are associated more with guided tours $[64,77,78]$, while in territorial degrees, such as Geography, they maintain a greater geographical link [79]. For Teacher Training degrees, fieldtrips are only, as Álvarez Piñeros et al. [45], a possibility. As Pagés and Santisteban [80] explain, when teachers become aware of what they are doing, they can act autonomously in their classroom and make relevant decisions. With our activity 
we show that teachers in training acquire that awareness and so they can then transmit everything learned in primary education classes, in a more meaningful way [81].

\section{Conclusions}

Understanding how contemporary urban dynamics such as tourism gentrification work is not easy, neither for a primary student nor for a teacher in training. Typically, depending on the curriculum, these issues are not even addressed despite being a topic of wide social concern. We thus believe that it must be part of the curriculum from primary education, in relation to the socio-economic contents of the social sciences area and in coherence with the critical and entrepreneurial spirit with which students are to be impregnated. Training future teachers is key to achieving this change. Doing it through fieldwork, in a significant city of the phenomenon studied, with consolidated didactic guidelines, applying basic geographical tools, is, in view of the results obtained, an ideal form of teaching experience.

To assess the extent to which the activity designed has achieved its objectives, it has been essential to implement an experience in one of the cities mentioned, with personal monitoring of its development and the direction of the final session of sharing, as well as being able to evaluate it through quantitative data from the questionnaire answered by the students. The evaluation may be improved if students' movements are monitored in a GIS software such as Google Maps embedded in devices like tablets or smartphones. Indeed, information and communication technologies (ICT) help add technological competences to the geographical ones.

From the decalogue of planned objectives, we have achieved them all to a greater or lesser extent, except that of social interaction. It seems that students have not grasped the importance of direct social sources, because of their shyness and lack of experience and confidence in fieldwork. Social interaction is an aspect to improve in future occasions. However, the central objective of the teaching experience, related to understanding the processes of tourism, gentrification and sustainability, has been widely covered, as well as the development of geographic techniques and tools for urban analysis and critical reflection of social phenomena. The students themselves are aware of these achievements and almost $80 \%$ of them would advise their implementation to their fellow students who have not participated in the activity, as reflected in the responses of the evaluation questionnaire. Moreover, on a scale from one to five, with five being the maximum value, students rate the teaching role of this experience with a very high score: $4.3 \pm 0.9$.

Therefore, fieldwork activities such as the current experience appear to be a good procedure to approach topics related to tourism and urban geography to teachers in training. It is advisable that tourism and urban geography have more curricular presence in the educational degrees. Thus, they will be able to transfer it to their future students.

Author Contributions: C.M.-H. and C.Y. conceived the theoretical framework, designed and performed the methodology, and wrote the paper. C.M.-H. also analysed the data and performed the cartography. All authors have read and agreed to the published version of the manuscript.

Funding: This research has been carried out with the support of the Ministry of Economy Project ref.: CSO2016-75470-R/PAITUR-Ciudad-2017-2019. Transformations of the Historical Urban Landscape Induced by Tourism: Contradictions and Disputes, Government and Local Governance.

Acknowledgments: The authors would like to thank the support of: (i) the students participating in the teaching activity, for their good predisposition, interest, motivation and collaboration; (ii) our partner Javier Robles, for his collaboration on the fieldtrip; (iii) ISEN University, for its logistical and economic assistance; and (iv) the editor and the anonymous reviewers for their constructive and high level contributions.

Conflicts of Interest: The authors declare no conflicts of interest. 


\section{References}

1. Santamaria, D.; Filis, G. Tourism demand and economic growth in Spain: New insights based on the yield curve. Tour. Manag. 2019, 75, 447-459. [CrossRef]

2. Novo Malvárez, M. New uses of heritage sites: The expansion of boutique hotels in Palma (Mallorca). Estoa 2019, 16, 83-95. [CrossRef]

3. Ashworth, G.; Page, S.J. Urban tourism research: Recent progress and current paradoxes. Tour. Manag. 2011, 32, 1-15. [CrossRef]

4. García-Hernández, M.; De la Calle-Vaquero, M.; Yubero, C. Cultural heritage and urban tourism: Historic city centres under pressure. Sustainability 2017, 9, 1346. [CrossRef]

5. Gravari-Barbas, M.; Guinand, S. Tourism and Gentrification in Contemporary Metropolises; Routledge: London, UK; New York, NY, USA, 2017.

6. Jafari, J. The Scientification of tourism. Politica Soc. 2005, 42, 39-56.

7. De Lázaro y Torres, M.L. Educar para el desarrollo sostenible desde la Geografía. In Aportaciones de la Geografía en el Aprendizaje a lo Largo de la Vida; Delgado Peña, J.L., de Lázaro y Torres, M.L., Marrón Gaite, M.J., Eds.; University of Málaga: Málaga, Spain, 2011; pp. 11-26.

8. Jamal, T.; Taillon, L.; Dredge, D. Sustainable tourism pedagogy and academic community collaboration: A progressive service-learning approach. Tour. Hosp. Res. 2011, 11, 133-147. [CrossRef]

9. Prebezac, D.; Schott, C.; Sheldon, P. The Tourism Education Futures Initiative. Activating Change in Tourism Education; Routledge: New York, NY, USA, 2014.

10. Belhassen, Y.; Caton, K. On the need for critical pedagogy in tourism education. Tour. Manag. 2011, 32, 1389-1396. [CrossRef]

11. Ortega Sánchez, D. La enseñanza de las Ciencias Sociales, las TIC y el tratamiento de la información y competencia digital (TICD) en el Grado de Maestro/a de Educación Primaria de las universidades de Castilla y León. Enseñanza Cienc. Soc. 2015, 14, 121-134.

12. Dogru, T.; Bulut, U. Is tourism an engine for economic recovery? Theory and empirical evidence. Tour. Manag. 2018, 67, 425-434. [CrossRef]

13. Clerval, A.; Colomb, C.; van Crieckingen, M. Les gentrifications des métropoles européennes. In Données Urbaines; Pumain, D., Mattei, M.F., Eds.; Economica Anthropos: Paris, France, 2011; pp. 151-165.

14. Cocola-Gant, A. Tourism and commercial gentrification. In Proceedings of the RC21 International Conference on the Ideal City: Between Myth and Reality. Representations, Policies, Contradictions and Challenges for Tomorrow's Urban Life, Urbino, Italy, 27-29 August 2015; Available online: https://www.rc21.org/en/wpcontent/uploads/2014/12/E4-C\%C3\%B3cola-Gant.pdf (accessed on 10 September 2019).

15. Aalbers, M. Introduction to the forum: From third to fifth-wave gentrification. Tijdschr. Voor Econ. Soc. Geogr. 2019, 110, 1-11. [CrossRef]

16. Gotham, K.F. Tourism gentrification: The case of New Orleans' Vieux Carré (French Quarter). Urban Stud. 2005, 42, 1099-1121. [CrossRef]

17. Wachsmuth, D.; Weiser, A. Airbnb and the rent gap: Gentrification through the sharing economy. Environ. Plan. A Econ. Space 2018, 50, 1147-1170. [CrossRef]

18. Fainstein, S.S.; Gladstone, D. Evaluating urban tourism. In The Tourist City; Judd, D.R., Fainstein, S., Eds.; Yale University Press: London, UK, 1999; pp. 21-34.

19. Degen, M. Barcelona's games: The Olympics, urban design, and global tourism. In Tourism Mobilities: Places to Play, Places in Play; Sheller, M., Urry, J., Eds.; Routledge: London, UK, 2004; pp. 131-142.

20. Romero Renal, L.; Lara Martín, L. Del barrio-problema al barrio de moda: Gentrificación comercial en Russa-fa, el "Soho" valenciano. An. Geogr. 2015, 35, 187-212.

21. Zukin, S. Naked City. The Death and Life of Authentic Urban Places; Oxford University Press: Oxford, UK, 2010.

22. Judd, D.R. Visitors and the spatial ecology of the city. In Cities and Visitors: Regulating People, Markets, and City Space; Hoffman, L., Fainstein, S., Judd, D.R., Eds.; Blackwell: Oxford, UK, 2003; pp. 23-38.

23. Larsen, J. Ordinary tourism and extraordinary everyday life: Re-thinking tourism and cities. In Tourism and Everyday Life in the City; Frisch, T., Stors, N., Stoltenberb, L., Sommer, C., Eds.; Routledge: London, UK, 2019.

24. Urry, J. The Tourist Gaze. Leisure and Travel in Contemporary Societies; Sage: London, UK, 1990.

25. Maitland, R. Everyday life as a creative experience in cities. Int. J. Cult. Tour. Hosp. Res. 2010, 4, 176-185. [CrossRef] 
26. Hiernaux, D.; Gonzalez, I. Turismo y gentrificación: Pistas teóricas sobre una articulación. Rev. Geogr. Norte Gd. 2014, 58, 55-70. [CrossRef]

27. Massey, D. A global sense of place. Marx. Today 1991, 38, 24-29.

28. Butler, T.; Lees, L. Super-gentrification in Barnsbury, London: Globalization and gentrifying global elites at the neighborhood level. Trans. Inst. Br. Geogr. 2006, 31, 467-487. [CrossRef]

29. Maitland, R. Conviviality and everyday life: The appeal of new areas for visitors. Int. J. Tour. Res. 2008, 10, 15-25. [CrossRef]

30. Füller, H.; Michel, B. 'Stop being a tourist!' New dynamics of urban tourism in Berlin-Kreuzberg. Int. J. Urban Reg. Res. 2014, 38, 1304-1318. [CrossRef]

31. Chapuis, A.; Gravari-Barbas, M.; Jacquot, S. Tourism/gentrification: Sex, gender and crossed resistances. In Proceedings of the Association of American Geographers Annual Meeting, Chicago, IL, USA, 21-25 April 2015; Available online: www.academia.edu/12256317/Tourism_Gentrification_Sex_gender_and_crosses_ resistances (accessed on 14 November 2019).

32. Baudry, S.L. Rome: A cultural capital with a poor working-class heritage: Strategies of touristification and artification. In Tourism and Gentrification in Contemporary Metropolises; Gravari-Barbas, M., Guinand, S., Eds.; Routledge: London, UK; New York, NY, USA, 2017; pp. 134-152.

33. Freitag, T.; Bauder, M. Bottom-up touristification and urban transformations in Paris. Tour. Geogr. 2018, 20, 443-460. [CrossRef]

34. Malet Calvo, D.; Gago, A.; Cócola-Gant, A. Turismo, negocio inmobiliario y movimientos de resistencia en Lisboa, Portugal. In Ciudad de Vacaciones. Conflictos Urbanos en Espacios Turísticos; Milano, C., Mansilla, J.A., Eds.; Pololen Edicions, Observatori Antropologia del Conflicte Urbá: Barcelona, Spain, 2018; pp. 121-153.

35. Barata-Salgueiro, T.; Mendes, L.; Guimarães, P.P.C. Tourism and urban changes: Lessons from Lisbon. In Tourism and Gentrification in Contemporary Metropolises; Gravari-Barbas, M., Guinand, S., Eds.; Routledge: London, UK; New York, NY, USA, 2017; pp. 255-275.

36. Benis, K. Vielas de Alfama. Entre Revitalização e Gentrificação. Impactos da «Gentrificação» Sobre a Apropriação do Espaço Público; Universidade Técnica de Lisboa: Lisboa, Portugal, 2011.

37. Quaglieri, A.; Scarnato, A. The Barrio Chino as last frontier: The penetration of everyday tourism in the dodgy heart of the Raval. In Tourism and Gentrification in Contemporary Metropolises; Gravari-Barbas, M., Guinand, S., Eds.; Routledge: London, UK; New York, NY, USA, 2017; pp. 107-135.

38. Maiello, V. El mercado de los mercados. Análisis de los procesos de transformación de los mercados municipales de abastos de Madrid. In Working Paper Series—Contested Cities; Grupo de Trabajo Mercados y Espacios Públicos ASF-Madrid: Madrid, Spain, 2015; Available online: http://contested-cities.net/working-papers/wpcontent/uploads/sites/8/2014/03/WPCC-14016_Maiello_vincenzo_elmercadodelosmercados.pdf (accessed on 10 September 2019).

39. Pérez, E. Gentrificación en Madrid: De la burbuja a la crisis. Rev. Geogr. Norte Gd. 2013, 58, 71-91.

40. Sequera, J.; Janoshka, M. Gentrification dispositifs in the historic centre of Madrid: A reconsideration of an urban governmentality and state-led urban gentrification. In Global Gentrifications: Uneven Development and Displacement; Lees, L., Shin, H., López-Morales, E., Eds.; Polity Press: London, UK, 2015; pp. 375-394.

41. Colomb, C.; Novy, J. Protest and Resistance in the Tourist City; Routledge: London, UK; New York, NY, USA, 2017.

42. Álvarez Piñeros, D.; Vásquez Ortiz, W.F.; Rodríguez Pizzinato, L.A. La salida de campo, una posibilidad en la formación inicial docente. Didáctica Cienc. Exp. Soc. 2016, 31, 61-77. [CrossRef]

43. Aguilera, D. La salida de campo como recurso didáctico para enseñar ciencias. Una revisión sistemática. Rev. Eureka Sobre Enseñanza Divulg. Cienc. 2018, 15, 3103. [CrossRef]

44. Crespo Castellanos, J.M.; Gómez Ruiz, M.L.; Cruz Naïmi, L.A. Una aproximación a los Parques Nacionales y sus paisajes a través de itinerarios didácticos. Espac. Tiempo Forma 2018, 11, 121-140. [CrossRef]

45. Council for Learning outside the Classroom. Learning Outside the Classroom. Manifesto; DfES Publications: Nottingham, UK, 2006.

46. Rajala, A.; Akkerman, S.F. Researching reinterpretations of educational activity in dialog interactions during a fieldtrip. Learn. Cult. Soc. Interact. 2019, 20, 32-44. [CrossRef]

47. Del Toro, R.; Morcillo, J.G. Las actividades de campo en educación secundaria. Un estudio comparativo entre Dinamarca y España. Enseñanza Cienc. Tierra 2011, 19, 39-47. 
48. Sorrentino, A.V.; Bell, P.E. A comparison of attributed values with empirically determined values of secondary school science field trips. Sci. Educ. 1970, 54, 233-236. [CrossRef]

49. Pedrinaci, E. Trabajo de campo y aprendizaje de las ciencias. Alambique 2012, 71, 81-89.

50. Rebelo, D.; Marqués, L.; Costa, N. Actividades en ambientes exteriores al aula en la educación en ciencias: Contribuciones para su operatividad. Enseñanza Cienc. Tierra 2011, 19, 15-25.

51. Turman, C. The outdoor classroom program: Fieldtrips empowered by technology. In Proceedings of the 12th International Technology, Education and Development Conference, Valencia, Spain, 5-7 March 2018; Chova, L.G., Martínez, A.L., Torres, I.C., Eds.; pp. 7534-7537.

52. Costillo, E.; Borrachero, A.B.; Esteban, R.; Sánchez-Martín, J. Aportaciones de las salidas al medio natural como actividades de enseñanza y de aprendizaje según profesores en formación. Indagatio Didáctica 2014, 6, 10-22.

53. Sagir, S.U. Reviewing science and nature activities of preschool teachers. Energy Educ. Sci. Technol. 2011, 3, 331-342.

54. Delgado Trujillo, A.; de Justo Moscardó, E. Evaluación del diseño, proceso y resultados de una asignatura técnica con aprendizaje basado en problemas. Educ. XX1 2018, 21, 179-203. [CrossRef]

55. Solbes, J. ¿Por qué disminuye el alumnado de ciencias? Alambique 2011, 67, 53-61.

56. Cañas, A.; Martín-Díaz, M.J. ¿Puede la competencia científica acercar la ciencia a los intereses del alumnado? Alambique 2010, 66, 80-87.

57. Gómez, C.J.; Miralles, P.; López, R.; Prats, J. Las competencias históricas en el horizonte. Propuestas presentes y perspectivas de futuro. In Enseñanza de la Historia y Competencias Educativas; López, R., Miralles, P., Prats, J., Eds.; Graó Ed.: Barcelona, Spain, 2017; pp. 215-227.

58. EHES. European Higher Education Space. Available online: http://www.eees.es/es/eees-estructuraseducativas-europeas (accessed on 30 October 2019).

59. González, J.; Wagenaar, R. Tuning Educational Structures in Europe II; University of Deusto: Bilbao, Spain, 2006.

60. Burriel, E. La 'década prodigiosa' del urbanismo español (1997-2006). Scr. Nova Rev. Electrónica Geogr. Cienc. Soc. 2008, XII, 64. Available online: http://www.ub.edu/geocrit/sn/sn-270/sn-270-64.htm (accessed on 8 October 2019).

61. Fernández Portela, J. La salida de campo como recurso didáctico para conocer el espacio geográfico: El caso de la ciudad de Valladolid y Soria. Didáctica Geográfica 2017, 18, 91-109.

62. De Lázaro y Torres, M.L.; Izquierdo Álvarez, S.; González González, M.J. Geodatos y paisaje: De la nube al aula universitaria. Boletín Asoc. Geógrafos Españoles 2016, 70, 371-391. [CrossRef]

63. Jiménez, L.S.; Vega, N.; Capa, E.D.; Fierro, N.C.; Quichimbo, P. Estilos y estrategias de enseñanza-aprendizaje de estudiantes universitarios de la ciencia del suelo. REDIE 2019, 21, e04. [CrossRef]

64. Rodríguez Cortés, A.B.; Díaz Velasco, E.A.; Carreño Cardozo, J.M. Turismo como agente educativo: Un análisis desde las salidas de campo. Tur. Soc. 2015, 16, 117-130. [CrossRef]

65. Sánchez Peral, J.L. Salida de campo por el valle del Henares y su canal de riego. Tarbiya Rev. Investig. Innovación Educ. 2018, 46, 55-72. [CrossRef]

66. Valverde Fernández, F.; Ramírez García, A.; Mora Márquez, M.; López Fernández, J.A.; Medina Quintana, S.; Arrebola Haro, J.C. Itinerarios interdisciplinares en el grado de educación primaria. Rev. Innovación Buenas Prácticas Docentes 2018, 6, 69-75. [CrossRef]

67. Sousa, S.; García, D.; Souto, X. Educación geográfica y las salidas de campo como estrategia didáctica: Un estudio comparativo desde el Geoforo Iberoamericano. Biblio3W Rev. Bibliográfica Geogr. Cienc. Soc. 2016, 155, 1-22.

68. Dillon, J.; Rickinson, M.; Tearney, K.; Morris, M.; Choi, M.-Y.; Sanders, D.; Benefield, P. The value of outdoor learning: Evidence from research in the UK and elsewhere. Sch. Sci. Rev. 2006, 87, 107-111.

69. Recommendation 2006/962/EC on Key Competences for Lifelong Learning. Available online: https: //eur-lex.europa.eu/legal-content/ES/TXT/?uri=LEGISSUM\%3Ac11090 (accessed on 30 October 2019).

70. Ley Orgánica 8/2013, de 9 de diciembre, para la mejora de la calidad educativa. Boletín Oficial del Estado 295, 10 December 2013.

71. Ministerio de Educación, Cultura y Deporte. Real Decreto 126/2014, de 28 de febrero, por el que se establece el currículo básico de la educación primaria. Boletín Oficial del Estado 52, 1 March 2014.

72. Ion, G.; Cano, E. University's teachers training towards assessment by competences. Educ. XX1 2019, 15, 249-270. 
73. Benejam, P. Los objetivos de las salidas. Iber Didáctica Cienc. Soc. Geogr. Hist. 2003, 36, 7-12.

74. Guerrero, M. Las salidas de campo como instrumento de aprendizaje. Dialéctica Libert. 2009, 2, $225-239$.

75. Martín Hernánz, S. Propuesta metodológica para el diseño de itinerarios didácticos de ciencias de la naturaleza. Didácticas Específicas 2016, 14, 135-143.

76. Martínez Hernández, C. Las Ideas Previas del Concepto 'Industria' en el Alumnado de Geografía de $3^{\circ}$ de la ESO. Las Salidas de Campo Locales Como Recurso Didáctico Para el Cambio y la Consolidación Conceptuales; Servicio de Publicaciones y Estadística de la CARM: Murcia, Spain, 2014.

77. García López, A.M.; Foronda-Robles, C. De la teoría a la práctica educativa: Las salidas de campo, instrumento de aproximación a la realidad profesional. Aplicación en el máster en dirección y planificación del turismo. In Nuevas Enseñas de Grado en la Escuela Universitaria de Estudios Empresariales de la Universidad de Sevilla; Jiménez-Caballero, J.L., Rodríguez Díaz, A., Eds.; GEU Ed.: Granada, Spain, 2010; pp. 38-50.

78. Íñiguez Berrozpe, L.; Íñiguez Berrozpe, T.; Melero Polo, I. Un análisis de las salidas de campo autogestionadas con el Grado en Turismo tras tres años de experiencia. CLIO Hist. Hist. Teach. 2017, 43, 242-250.

79. Tulla, A. Los nuevos planes de estudio de los títulos de grado en geografía adaptados al modelo del espacio Europeo de educación superior (EEES). Estud. Geográficos 2010, LXXXI, 319-338.

80. Pagés, J.; Santisteban, A. Una mirada del pasado al futuro en la didáctica de las ciencias sociales. In Una Mirada al Pasado y un Proyecto de Futuro. Investigación e Innovación en Didáctica de las Ciencias Sociales; Pagés, J., Santisteban, A., Eds.; Universitat Autònoma de Barcelona: Barcelona, Spain, 2014; pp. 17-41.

81. Garello, M.V.; Rinaudo, M.C. Autorregulación del aprendizaje, feedback y transferencia de conocimiento. Investigación de diseño con estudiantes universitarios. REDIE 2013, 15, 131-147.

(C) 2019 by the authors. Licensee MDPI, Basel, Switzerland. This article is an open access article distributed under the terms and conditions of the Creative Commons Attribution (CC BY) license (http://creativecommons.org/licenses/by/4.0/). 